\title{
Platelet-activating factor acts on cortisol secretion by perfused guinea-pig adrenals via calcium-/phospholipid-dependent mechanisms
}

\author{
Toshio Shimada, Taeko Hirose, Itsuro Matsumoto and \\ Tadaomi Aikawa
}

Department of Physiology, Nagasaki University School of Medicine, Nagasaki 852-8523, Japan

(Requests for offprints should be addressed to T Shimada; Email: tshimada@net.nagasaki-u.ac.jp)

\begin{abstract}
Bilateral adrenals of the guinea pig were perfused in situ with an artificial medium equilibrated with $95 \% \mathrm{O}_{2} / 5 \%$ $\mathrm{CO}_{2}$. Platelet-activating factor (PAF) induced biphasic cortisol responses, which reached a maximum at $10 \mathrm{nM}$ PAF and declined at $100 \mathrm{nM}$. The effect of the PAF receptor antagonists CV-3988 and CV-6209 on PAFstimulated cortisol secretion was examined. Prior exposure of adrenal glands to $10 \mu \mathrm{M} \mathrm{CV-3988} \mathrm{or} \mathrm{a} \mathrm{simultaneous}$ incubation with $10 \mu \mathrm{M}$ CV-6209 abolished the cortisol response to $10 \mathrm{nM}$ PAF. Lyso-PAF (a PAF precursor and breakdown product) did not affect cortisol secretion. Concentrations of $5-12.5 \mu \mathrm{M}$ 1-(5-isoquinolinesulfonyl)-2methylpiperazine dihydrochloride (H-7), a protein kinase $\mathrm{C}$ (PKC) inhibitor, abolished subsequent cortisol secretion in response to $10 \mathrm{nM}$ PAF. $\mathrm{N}$-[2-(Methylamino)ethyl]-5isoquinoline sulfonamide dihydrochloride $(\mathrm{H}-8)$, a protein
\end{abstract}

kinase A inhibitor, was less effective. A calcium ionophore (A23187) at 3.3 and $10 \mu \mathrm{M}$ increased cortisol secretion, but the activator of PKC, L- $\alpha-1$-oleoyl-2-acetyl-sn-3glycerol (OAG), at $50 \mu \mathrm{M}$ had no effect. When infused simultaneously, OAG $(50 \mu \mathrm{M})$ and A23187 $(3 \cdot 3 \mu \mathrm{M})$ stimulated cortisol secretion synergistically. The secretory response of cortisol to repeated infusions of adrenocorticotrophin $(100 \mathrm{pg} / \mathrm{ml})$ or forskolin $(10 \mu \mathrm{M})$ was essentially reproducible. By contrast, cortisol secretion in response to repeated infusions of PAF (10 nM) or OAG plus A23187 was not reproducible and the second response was diminished compared with the first. Our findings suggest that PAF plays a role in the regulation of steroidogenesis via a mechanism mediated by the PAF receptor and PKC.

Journal of Endocrinology (2005) 184, 381-391

\section{Introduction}

A potent mediator of inflammatory and allergic processes, platelet-activating factor (PAF) is released by various cells such as macrophages, neutrophils, basophils, mast cells, endothelial cells and platelets (Braquet et al. 1987). In addition, PAF is involved in a wide spectrum of biological processes, such as hepatic glycogenolysis (Buxton et al. 1984), exocytosis in exocrine glands (Söling et al. 1984), ovoimplantation and labor (Baldi et al. 1994). The intracerebroventricular injection of PAF stimulates the release of hypothalamic corticotrophin-releasing factor and increases plasma levels of adrenocorticotrophin (ACTH) and corticosterone in the rat (Rougeot et al. 1990). We found that PAF significantly increases glucocorticoid output from the perfused canine adrenal gland (Aikawa et al. 1991). Infusing PAF into the perfused adrenal glands of CD1 ICR mice does not induce a significant corticosterone response (Yang et al. 1995), whereas $N$-methylcarbamylPAF, a PAF agonist that cannot be metabolized, weakly but significantly stimulates corticosterone release (Han et al. 1998). These data indicate a species-dependent difference in PAF-induced corticosteroidogenesis. Bovine adrenocortical cells can synthesize and release PAF and have high-affinity binding sites for PAF (Pelosin et al. 1991).

The binding of PAF to its receptor in many PAFresponsive cells is accompanied by inositol phospholipid hydrolysis by phospholipase $\mathrm{C}$ and the rapid accumulation of $s n$-1,2-diacylglycerol and inositol 1,4,5-trisphosphate. These second messengers subsequently promote calcium mobilization and protein kinase $\mathrm{C}$ (PKC) activation (Shimizu et al. 1992). Thus, PKC might participate in the production of glucocorticoids in fasciculata cells.

The present study examines whether PAF can act on cortisol secretion by the perfused guinea-pig adrenal via the PAF receptor and PKC activation.

\section{Materials and Methods}

\section{Animals}

Adult male guinea pigs (Hartley), weighing 480-850 g each, were group-housed in cages with suspended steelmesh floors in a well-ventilated room maintained at $25^{\circ} \mathrm{C}$ 
under a $12 \mathrm{~h}$ light:12 h darkness. Sterilized laboratory guinea-pig chow and water were available ad libitum. The protocols conformed to the guidelines governing animal experimentation issued by the Animal Care and Use Committee of our university and by the Japanese Government (Law No. 105, 1 Oct 1973).

\section{Drugs and reagents}

We purchased 1-O-hexadecyl- and octadecyl-2-acetylsn-glycero-3-phosphocholine $\left(\mathrm{C}_{16} \mathrm{PAF}\right.$ and $\left.\mathrm{C}_{18} \mathrm{PAF}\right)$ and 1-O-hexadecyl-sn-glycero-3-phosphocholine $\left(\mathrm{C}_{16}\right.$ lysoPAF) from Bachem (Bettendorf, Switzerland). Synthetic adrenocorticotrophic hormone 1-24 (ACTH; Cortrosyn) was obtained from Organon (Boxtel, Holland). The PAF receptor antagonists CV-3988 and CV-6209 were gifts from the Central Research Division of Takeda Chemical Industries (Osaka, Japan). 1-(5-Isoquinolinesulfonyl)-2methylpiperazine dihydrochloride (H-7), a PKC inhibitor, and $\mathrm{N}$-[2-(methylamino)ethyl]-5-isoquinoline sulfonamide dihydrochloride (H-8), a protein kinase A inhibitor, were purchased from Seikagaku Kogyo Co. (Tokyo, Japan). Forskolin was purchased from Wako Pure Chemical Industries (Osaka, Japan) and L- $\alpha-1$-oleoyl-2acetyl-sn-3-glycerol (OAG) was obtained from Avanti Polar-Lipids (Alabaster, AL, USA). Krebs-Ringer bicarbonate glucose (KRBG) solution contained $121 \mathrm{mM}$ $\mathrm{NaCl}, 2 \cdot 37 \mathrm{mM} \mathrm{KCl}, 1 \cdot 19 \mathrm{mM} \mathrm{MgSO} \cdot \cdot 7 \mathrm{H}_{2} \mathrm{O}, 1 \cdot 19 \mathrm{mM}$ $\mathrm{KH}_{2} \mathrm{PO}_{4}, 2 \cdot 54 \mathrm{mM} \mathrm{CaCl} \cdot 2 \mathrm{H}_{2} \mathrm{O}, 25 \mathrm{mM} \mathrm{NaHCO}$ and $10 \mathrm{mM}$ glucose.

\section{Perfusion of adrenal glands}

The bilateral adrenal glands of guinea pigs were perfused in situ with fresh KRBG containing $0 \cdot 2 \%$ BSA and equilibrated with $95 \% \mathrm{O}_{2} / 5 \% \mathrm{CO}_{2}$. Animals were anesthetized with an i.p. injection of pentobarbital sodium (Somnopentyl; 3.8 mg/100 g; Pitman-Moore, Washington Crossing, NJ, USA), and the abdomen was incised through the midline $10 \mathrm{~min}$ thereafter. The celiac, superior mesenteric and inferior mesenteric arteries as well as the esophagus, vena portae, bile duct and colon were ligated and resected. The animals were then eviscerated. The renal arteries and veins were ligated at the hilum of the kidney on both sides. We isolated the bilateral adrenal circulation by ligating the iliolumbar, subcostal, internal spermatic and small vessels on both sides of the lumboabdominal region. The abdominal aorta and the inferior vena cava were separately ligated above the bifurcation and sutures were loosely passed around the aorta and inferior vena cava below the renal vessels. A cannula (i.v. catheter; ATOM, Tokyo, Japan) was inserted into the abdominal aorta. The top of the cannula was placed below the renal arteries and ligated. The cannula was connected to a silicon tube that was covered with a water jacket maintained at $38^{\circ} \mathrm{C}$ by circulating water (Thermo
Minder; Taiyo, Saitama, Japan). The tube was attached to the long arm of a silicon T-tube (Phicon no. 5; Fuji Systems, Tokyo, Japan). A mini-pump (SJ-1211; Atto, Tokyo, Japan) was placed between the water jacket and the trifurcation of the T-tube. One short arm of the T-tube was connected to a large flask that contained KRBG plus $0 \cdot 2 \%$ BSA and the other short arm was attached to a smaller flask that contained test compounds dissolved in the same solution. Both flasks were placed in a water bath maintained at $38{ }^{\circ} \mathrm{C}$ and bubbled with a gaseous mixture of $95 \% \mathrm{O}_{2} / 5 \% \mathrm{CO}_{2}$ to maintain the $\mathrm{pH}$ at $7 \cdot 4$. One suture was loosely passed around the aorta below the diaphragm and another was passed around the inferior vena cava just above the right adrenal gland. Perfusion medium was introduced into the catheter in the abdominal aorta from the large flask via the mini-pump. The bilateral adrenal glands paled during perfusion with the medium immediately after the aorta was ligated with a suture that had been passed around it below the diaphragm. To stop the outflow from the lumbar arteries to the thoracic region, the muscles around the vertebral column were ligated together with the aorta and vertebral column by a suture at the crura of the diaphragm. Pentobarbital sodium $(2 \mathrm{ml}, 64.8 \mathrm{mg} / \mathrm{ml})$ was injected subcutaneously and we confirmed that the heartbeat had stopped. Blood was washed out through a small hole cut in the inferior vena cava below the renal veins and perfusion was continued for about 20 min until the effluent perfusate became clear. Another cannula (constructed in-house from a silicon tube and an i.v. catheter) was inserted into the hole in the inferior vena cava and ligated immediately below the renal veins with the suture that had been passed around the inferior vena cava. Finally, the suture that had been passed around the inferior vena cava immediately above the right adrenal gland was ligated to direct the bilateral adrenal venous flow towards the exterior. About $40 \mathrm{~min}$ was required from laparotomy to the initial perfusion. The animal was placed in an acrylic chamber maintained at $38^{\circ} \mathrm{C}$. During all experiments, the adrenal glands were perfused for $40 \mathrm{~min}$ to allow equilibration before the start of any test procedures. Forskolin, ACTH, $\mathrm{PAF}$, or OAG plus the calcium ionophore A23187 were dissolved in KRBG plus $0 \cdot 2 \%$ BSA and infused into the adrenal glands over a period of $5 \mathrm{~min}$ from the smaller flask. Fractions of the perfusate were collected for $5 \mathrm{~min}$ before and every $5 \mathrm{~min}$ after starting the infusion of ACTH and forskolin or for 5 min before and every 2.5 or 5 min after starting the infusion of PAF and OAG plus A23187. CV-3988 $(10 \mu \mathrm{M})$, dissolved in KRBG plus $0 \cdot 2 \%$ BSA, was infused simultaneously with PAF or over a period of $5 \mathrm{~min}$ from 20 or $35 \mathrm{~min}$ before the PAF infusion. CV-6209 $(10 \mu \mathrm{M})$, dissolved in KRBG plus $0 \cdot 2 \%$ BSA, was infused simultaneously with PAF. H-7 $(0 \cdot 25-12 \cdot 5 \mu \mathrm{M})$ or $\mathrm{H}-8(0 \cdot 5-25 \mu \mathrm{M})$ dissolved in KRBG plus $0 \cdot 2 \%$ BSA was infused over 5 min starting $10 \mathrm{~min}$ before the infusion of ACTH or PAF. 
The perfusate was collected in graduated glass tubes on ice, and then contaminating blood cells were removed by centrifugation and the supernatant was extracted with methylene chloride.

We used hexadecyl-PAF $\left(\mathrm{C}_{16} \mathrm{PAF}\right)$ unless otherwise noted. The average weight of a pair of perfused adrenal glands was $290 \pm 5 \mathrm{mg}$ (mean \pm S.E.M., $n=204$ ). The respective flow rates during the $5 \mathrm{~min}$ before and $5 \mathrm{~min}$ after the administration of ACTH and forskolin were as follows (means \pm S.E.M., $n=6$ ): ACTH $(100 \mathrm{pg} / \mathrm{ml}), 1 \cdot 70 \pm 0 \cdot 06$ and $1.66 \pm 0.14 \mathrm{ml} / \mathrm{min}$; forskolin $(10 \mu \mathrm{M}), 1.78 \pm 0.07$ and $2.33 \pm 0.14 \mathrm{ml} / \mathrm{min}$. The respective flow rates during the $5 \mathrm{~min}$ before and $2.5 \mathrm{~min}$ after the administration of PAF or OAG plus A23187 were as follows (means \pm S.E.M., $n=6)$ : PAF $(10 \mathrm{nM}), 1.94 \pm 0.08$ and $2.24 \pm 0.34 \mathrm{ml} /$ min; OAG $(50 \mu \mathrm{M})$ plus A23187 $(3 \cdot 3 \mu \mathrm{M}), 1 \cdot 73 \pm 0.09$ and $2 \cdot 03 \pm 0 \cdot 07 \mathrm{ml} / \mathrm{min}$.

\section{Biochemical analysis}

Cortisol and corticosterone in perfusate extracts were quantified by thin-layer chromatography followed by fluorometry (Hirose 1977). We calculated the secretion rates of cortisol and corticosterone (ng/100 mg adrenal weight per min) by multiplying the concentration of the steroid $(\mathrm{ng} / \mathrm{ml})$ by the adrenal flow $(\mathrm{ml} / \mathrm{min})$ per $100 \mathrm{mg}$ adrenals. The total secretion of cortisol during the 30- or 15-min period after the onset of infusion of ACTH, forskolin, PAF, or OAG plus A23187 over the basal value (immediately before infusion of compounds) was calculated. We measured catecholamine levels in the perfusate by coulometric electrochemical determination, with a minor modification as reported by Matsumoto et al. (1994).

\section{Statistical analysis}

Results are expressed as means \pm S.E.M. Data were analyzed using STATISTICA software (Stat Soft, Tulsa, OK, USA). Mean secretory rates during each period and the dose-dependent secretion of cortisol were statistically compared by one- or two-way ANOVA, followed by the Newman-Keuls post hoc test for multiple comparisons. Student's $t$-test (two-tailed) for paired data compared sets of two values. Statistical significance was established at $P<0 \cdot 05$.

\section{Results}

\section{Secretory responses to ACTH}

Figure 1 shows the secretory responses of cortisol to increasing amounts of ACTH (the inset shows the total amount of secreted cortisol). Rates of cortisol secretion increased dose-dependently in response to ACTH infu- sions of 1,10 and $100 \mathrm{pg} / \mathrm{ml}$. The cortisol response to ACTH significantly increased at $10 \mathrm{pg} / \mathrm{ml}$ and peaked at $100 \mathrm{pg} / \mathrm{ml}$. The peak of the cortisol response to $1000 \mathrm{pg} / \mathrm{ml}$ ACTH reached a plateau at 5-10 min that persisted thereafter.

\section{Secretory responses to PAF}

Figure 2 shows the secretory responses of cortisol to increasing amounts of PAF (the inset shows the total amount of secreted cortisol). Rates of cortisol secretion in response to $0 \cdot 01,0 \cdot 1,1$ and $10 \mathrm{nM}$ PAF increased dose-dependently. Cortisol secretion peaked $2 \cdot 5-5 \mathrm{~min}$ after the infusion of PAF and then decreased to the basal level within 15-20 min. In response to $10 \mathrm{nM}$ PAF, the duration of cortisol secretion was shorter and the peak was higher and earlier than those induced by $100 \mathrm{pg} / \mathrm{ml}$ ACTH. The response to PAF increased significantly at $0 \cdot 1 \mathrm{nM}$ and maximally at $10 \mathrm{nM}$. The response to PAF at $100 \mathrm{nM}$ declined as compared with that at $10 \mathrm{nM}$.

Effect of PAF receptor antagonists, CV-3988 and CV-6209, on PAF-induced cortisol secretion

When concurrently applied with $10 \mathrm{nM}$ PAF, $10 \mu \mathrm{M}$ CV-3988 did not inhibit the PAF-induced increase in cortisol secretion (Fig. 3). However, when adrenal glands were exposed to $10 \mu \mathrm{M} \mathrm{CV}-3988$ for 15 and $30 \mathrm{~min}$ before infusion with PAF, the cortisol response to PAF was inhibited by 43.7 and $41.7 \%$ respectively. Thus, the inhibitory effect apparently depended on the duration of the incubation after exposure to CV-3988. By contrast, $10 \mu \mathrm{M} \mathrm{CV}-6209$ infused together with PAF significantly inhibited the cortisol response. CV-3988 or CV-6209 did not induce any changes in the cortisol response.

\section{Secretory responses to $C_{18} P A F$ and lyso-PAF}

Figure 4 compares the secretory responses of cortisol to $\mathrm{C}_{18}$ PAF, $\mathrm{C}_{16}$ lyso-PAF and PAF. The rates of cortisol secretion in response to $10 \mathrm{nM} \mathrm{C}_{18} \mathrm{PAF}$ at $0-2 \cdot 5,2 \cdot 5-5$ and $5-10 \mathrm{~min}$ were $20 \cdot 6,28 \cdot 4$ and $83 \cdot 7 \%$ respectively, as compared with those to $10 \mathrm{nM}$ PAF. The total amount of cortisol secreted in response to $\mathrm{C}_{18}$ PAF was $52.5 \%$ of that induced by PAF (Fig. 4, inset). Lyso-PAF did not induce any changes in the cortisol response.

\section{Effects of H-7 and H-8 on PAF-induced cortisol secretion}

The PKC and protein kinase A inhibitors $\mathrm{H}-7$ and $\mathrm{H}-8$ respectively, did not induce changes in the cortisol response. We infused adrenal glands with $0 \cdot 25,0 \cdot 5,5$ and $12 \cdot 5 \mu \mathrm{M} \mathrm{H}-7$ or with $0 \cdot 5,5,12 \cdot 5$ and $25 \mu \mathrm{M} \mathrm{H}-8$ for over 5 min, starting $10 \mathrm{~min}$ before the infusion of $10 \mathrm{nM}$ PAF (Table 1 ). H-7 (5 and $12 \cdot 5 \mu \mathrm{M}$ ) significantly and dosedependently inhibited cortisol secretion. The predicted 


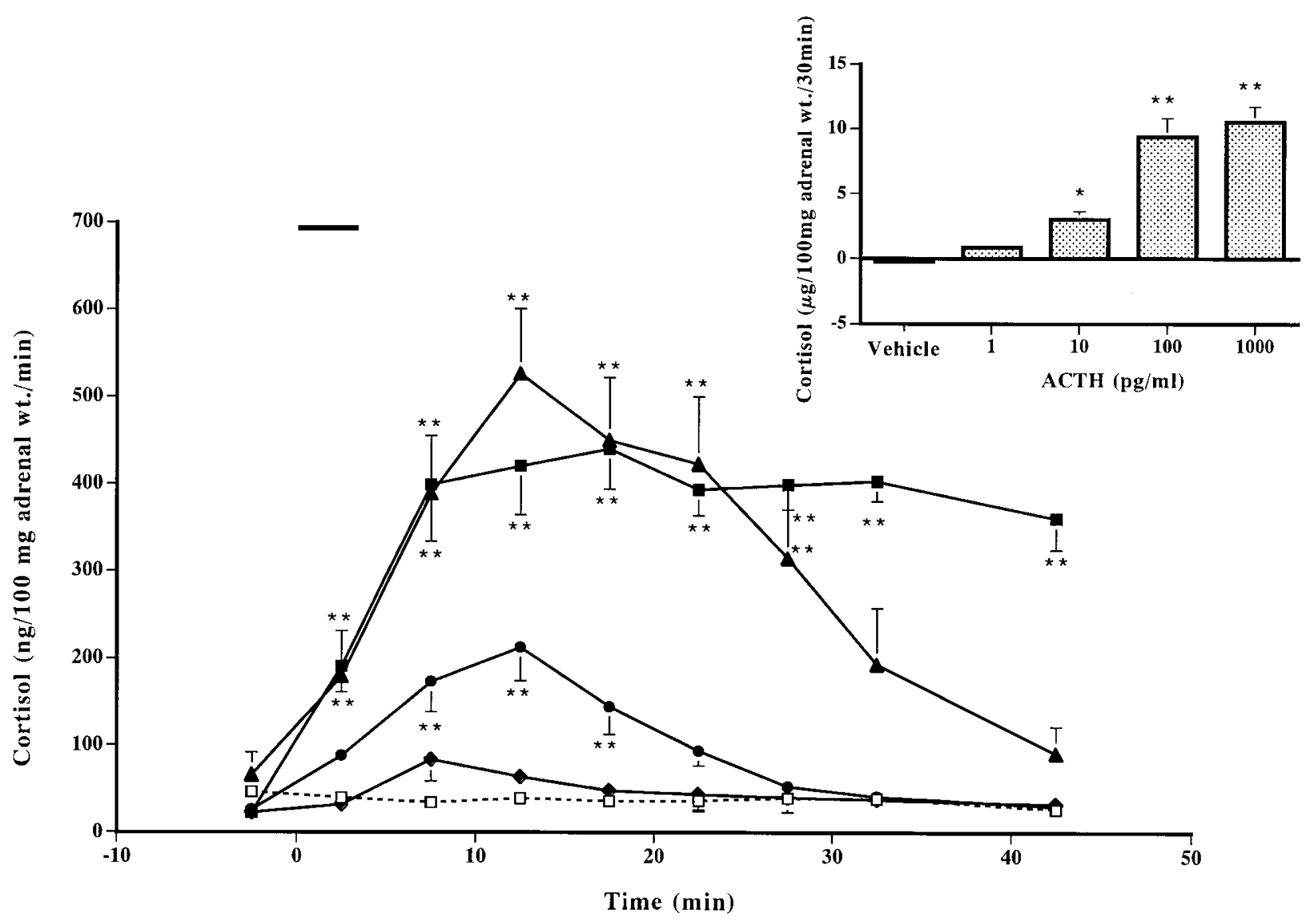

Figure 1 Secretory responses of cortisol to ACTH. Vehicle $(\square)$ or ACTH at $1(\diamond), 10(\boldsymbol{\bullet}), 100(\boldsymbol{\Delta})$ or $1000(\boldsymbol{\square}) \mathrm{pg} / \mathrm{ml}$ was infused (bar above curves) over $5 \mathrm{~min}$ and cortisol secretion was monitored. Inset: total amounts of cortisol secretion for $30 \mathrm{~min}$ after ACTH administration. Values are means \pm S.E.M., $n=6 .{ }^{*} P<0 \cdot 05,{ }^{*} P<0 \cdot 01$ versus vehicle control.

value for $50 \%$ inhibition $\left(\mathrm{IC}_{50}\right)$ was about $3.0 \mu \mathrm{M}$, and $5 \mu \mathrm{M} \mathrm{H}-7$ caused approximately $62 \%$ inhibition. $\mathrm{H}-8$ was less inhibitory than $\mathrm{H}-7$ with respect to PAF-induced cortisol secretion.

Synergistic effects of diacylglycerol (OAG) and calcium ionophore A23187 on cortisol secretion

To confirm whether PKC participates in cortisol secretion from perfused guinea-pig adrenals, we examined the effect of a direct PKC activator. Figure 5 shows the cortisol responses to $50 \mu \mathrm{M}$ OAG, $3 \cdot 3$ and $10 \mu \mathrm{M}$ A23187, and a mixture of $50 \mu \mathrm{M}$ OAG and $3 \cdot 3 \mu \mathrm{M}$ A23187. Diacylglycerol did not affect the rate of cortisol secretion. At both tested concentrations, A23187 alone increased cortisol secretion and peaked 5-10 $\mathrm{min}$ after the infusion of A23187. However, when $50 \mu \mathrm{M}$ OAG and $3 \cdot 3 \mu \mathrm{M}$ A23187 were infused together, the cortisol response increased more than that caused by $3.3 \mu \mathrm{M}$ A23187 alone. The rate of secretion peaked $2 \cdot 5-5$ min after infusion of the mixture. The total amount of cortisol secreted after starting infusion of the mixture $(3 \cdot 0 \pm 0 \cdot 2 \mu \mathrm{g} / 100 \mathrm{mg}$ adrenals per $15 \mathrm{~min}$ ) was much greater than the arithmetic sum of the amounts secreted in response to each agent alone $(50 \mu \mathrm{M}$ OAG alone, $0 \cdot 3 \pm 0 \cdot 1 \mu \mathrm{g} / 100 \mathrm{mg}$ adrenals per $15 \mathrm{~min} ; 3 \cdot 3 \mu \mathrm{M}$ A23187 alone, $1 \cdot 3 \pm 0 \cdot 3 \mu \mathrm{g} / 100 \mathrm{mg}$ adrenals per $15 \mathrm{~min}$; Fig. 5, inset). The concentration of A23187 $(3 \cdot 3 \mu \mathrm{M})$ was critical, since a higher concentration $(10 \mu \mathrm{M}, 1.8 \pm 0.6 \mu \mathrm{g} / 100 \mathrm{mg}$ adrenals per $15 \mathrm{~min}) \mathrm{did}$ not act synergistically with OAG $(50 \mu \mathrm{M}$ OAG plus $10 \mu \mathrm{M} \quad$ A23187, $2 \cdot 3 \pm 0 \cdot 4 \mu \mathrm{g} / 100 \mathrm{mg}$ adrenals per $15 \mathrm{~min})$. A23187 might have nonspecifically activated calcium-dependent enzymes by significantly increasing the $\mathrm{Ca}^{2+}$ concentration.

Secretory responses to repeated infusion of $A C T H$, forskolin, $P A F$, and $O A G$ plus $A 23187$

Figure 6A shows the reproducibility of cortisol and corticosterone secretion in response to repeated infusions of $100 \mathrm{pg} / \mathrm{ml} \mathrm{ACTH}$. The values for total cortisol and corticosterone secretion in response to the second infusion 


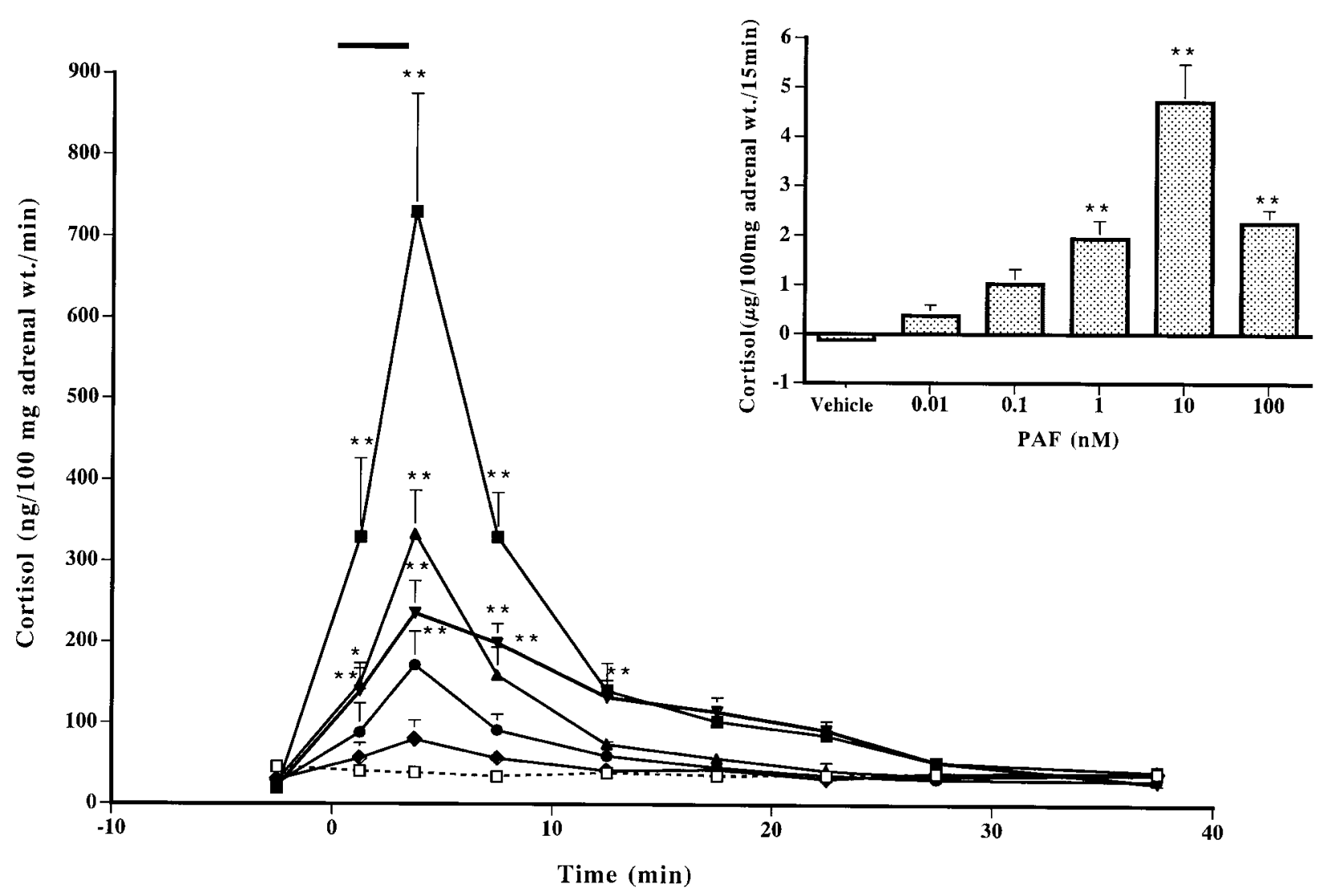

Figure 2 Secretion of cortisol in response to PAF. Vehicle $(\square)$ or PAF at 0.01 ( ), 0.1 $(\boldsymbol{\bullet}), 1(\boldsymbol{\Delta}), 10(\boldsymbol{\square})$ or $100(\boldsymbol{\nabla})$ nM was infused (bar above curves) over $5 \mathrm{~min}$ and cortisol secretion was monitored. Inset: total amounts of cortisol secretion for 15 min after PAF administration. Values are means \pm S.E.M., $n=6$. ${ }^{*} P<0 \cdot 05,{ }^{*} P<0 \cdot 01$ versus vehicle control.

of ACTH were $99 \cdot 7$ and $74 \cdot 1 \%$ respectively, of the values after the first infusions. We examined cortisol secretion in response to repeated infusions of $10 \mu \mathrm{M}$ forskolin (Fig. $6 \mathrm{~B})$. The second response to forskolin was $90 \cdot 1 \%$ of the first infusion. The secretory responses of cortisol to ACTH and forskolin were essentially reproducible. We examined whether the adrenal responses of cortisol secretion induced by repeated exposure to $10 \mathrm{nM}$ PAF or $50 \mu \mathrm{M}$ OAG plus $3 \cdot 3 \mu \mathrm{M}$ A23187 were reproducible. Figure 7 shows that the second infusion of PAF or OAG plus A23187 only slightly increased cortisol secretion. The total amount of cortisol secreted during the second infusion was 31.7 or $21.7 \%$ of that of the first infusion. Thus, the adrenals were desensitized by a second infusion of the two compounds.

\section{Secretory response of epinephrine and norepinephrine to $P A F$}

The administration of $10 \mathrm{nM}$ PAF did not alter catecholamine levels in the perfusate $(5-1 \mathrm{~min}$ before, and $0-2 \cdot 5$ and $2 \cdot 5-5 \mathrm{~min}$ after PAF administration: adrenaline, $22 \cdot 6 \pm 8 \cdot 5,29 \cdot 6 \pm 12 \cdot 4$ and $19 \cdot 6 \pm 6 \cdot 7 \mathrm{ng} / \mathrm{ml}$ per $100 \mathrm{mg}$ adrenals per min; noradrenaline, $1.2 \pm 0.5, \quad 1.7 \pm 0.8$ and $1.0 \pm 0.4 \mathrm{ng} / \mathrm{ml}$ per $100 \mathrm{mg}$ adrenals per min; means \pm S.E.M., $n=3$ ).

\section{Discussion}

The present study discovered that cortisol output in response to PAF is mediated by a PKC-dependent mechanism and that it can be desensitized.

Surgery involving laparotomy or manipulation of the visceral organs is probably associated with massive secretion of ACTH. However, low basal rates of cortisol secretion that were evident after starting perfusion increased dose-dependently in response to ACTH (Fig. 1). The maximal secretory rate of cortisol in response to 100 or $1000 \mathrm{pg} / \mathrm{ml} \mathrm{ACTH}$ was greater than the response to approximately $300 \mathrm{pg} / \mathrm{ml}$ ACTH in the dog adrenal (323 $\pm 64 \mathrm{ng} / 100 \mathrm{mg}$ adrenals per min), perfused with arterial blood from a hypophysectomized/nephrectomized $\operatorname{dog}$ (T Aikawa, T Hirose, I Matsumoto \& T Suzuki, 


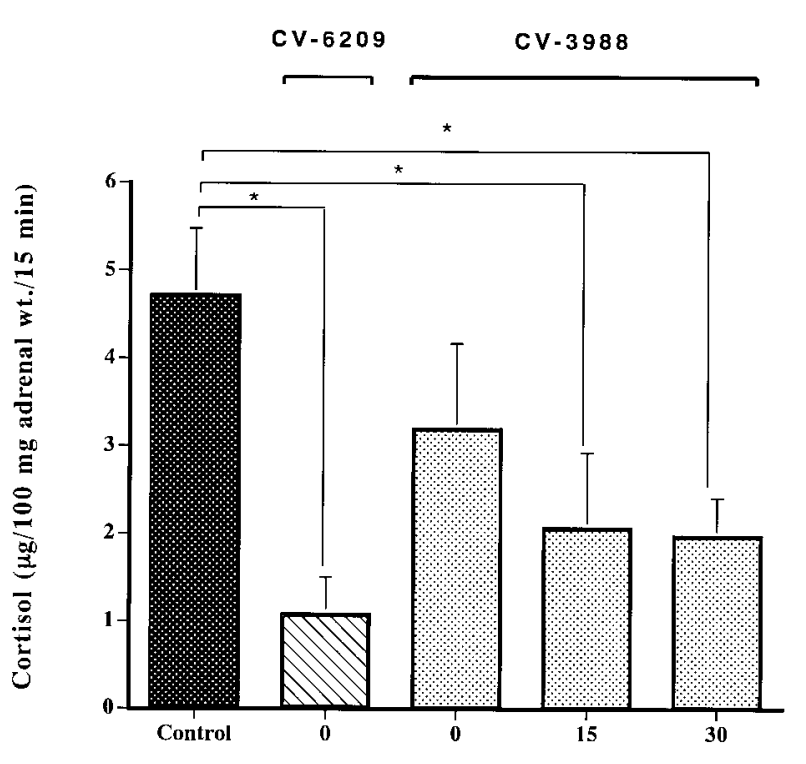

Pretreatment time (min)

Figure 3 Inhibitory effects of CV-3988 and CV-6209 on PAF-induced cortisol secretion. PAF $(10 \mathrm{nM})$ was infused with or without $10 \mu \mathrm{M} \mathrm{CV}-3988$ or CV-6209 over 5 min (control or pretreatment time 0). CV-3988 was infused over 5 min from 20 or 35 min before PAF infusion (pretreatment time 15 or $30 \mathrm{~min}$ ). Cortisol secretion in response to PAF with and without (control) inhibitor was compared. Values are means \pm S.E.M., $n=6$. ${ }^{*} P<0 \cdot 05$ versus control.

unpulished observations). Therefore, our perfusion system using an artificial medium can evaluate both the dynamics of secretion and the acute effects of compounds on the stimulated release of cortisol. The repeated secretory responses of cortisol to $100 \mathrm{pg} / \mathrm{ml} \mathrm{ACTH}$ at $45 \mathrm{~min}$ intervals were very high and reproducible (Fig. 6). This finding indicates that high levels of biosynthesized steroid precursors are located in the adrenals, although the perfusion medium did not contain cholesterol or any other steroid precursors except glucose.

Epinephrine directly stimulates cortisol secretion via an $\alpha$-adrenergic mechanism in perfused adrenal glands of the guinea pig (Mokuda et al. 1992). However, $10 \mathrm{nM}$ PAF did not evoke catecholamine release in the adrenal medulla in the present study. Hence, PAF probably stimulates cortisol release via a mechanism that does not include epinephrine.

The secretion of cortisol in response to PAF increased significantly at $0.1 \mathrm{nM}$, more at $1 \mathrm{nM}$ and maximally at $10 \mathrm{nM}$ and the response to $100 \mathrm{nM}$ PAF was smaller than that to $10 \mathrm{nM}$ PAF (Fig. 2). The maximal cortisol response to $10 \mathrm{nM}$ PAF was higher than that to 100 or $1000 \mathrm{pg} / \mathrm{ml}$ ACTH and the response declined sharply within $15 \mathrm{~min}$. The PAF concentrations required to cause $50 \%$ maximal platelet aggregation and 20\% maximal platelet ATP secre- tion in guinea pig are 0.41 and $0.56 \mathrm{nM}$ respectively (Coëffier et al. 1986). The minimal effective concentration of PAF $(0 \cdot 1 \mathrm{nM})$ for cortisol secretion was almost identical to that required for platelet aggregation and activation.

PAF acetylhydrolase rapidly metabolizes PAF to an inactive form (Stafforini et al. 1987). PAF circulates in the peripheral blood at subnanomolar or nanomolar concentrations in humans, rabbits and rats under physiological conditions (Caramelo et al. 1984). Domain II of extracellular albumin is an exclusive acceptor for PAF released by cells (Ammit \& O'Neill 1997) and binding to it might increase the half-life of PAF. If the adrenocortical cells are exposed to subnanomolar concentrations of PAF in the perivascular space fluid of the zona fasciculata and zona reticularis under immediate hypersensitivity or severe inflammation, cortisol release will be evoked.

Our previous studies of dogs showed that PAF at $1 \mathrm{nM}$ in the perfused adrenal and $0 \cdot 1 \mathrm{nM}$ in adrenocortical cells causes significant amounts of cortisol release (Aikawa et al. 1991). PAF potently stimulates the adrenal cortex of both guinea pigs and dogs. On the other hand, infusing PAF into the perfused adrenals of mice did not induce a significant corticosterone response (Yang et al. 1995). The administration of PAF does not evoke corticosterone production in dispersed rat adrenocortical cells (T Shimada, $\mathrm{T}$ Hirose, I Matsumoto \& $\mathrm{T}$ Aikawa, unpublished observations). These data indicate a species difference in PAF-induced glucocorticoid release. The ACTH-induced secretion of corticosterone in the present study was $1.5 \%$ that of cortisol. The adrenal cortex of guinea pigs secretes mainly cortisol. Guinea pigs, dogs and humans are corticosteroid-resistant, and the adrenals of these animals secrete mainly cortisol. On the other hand, the adrenal cortex of corticosteroid-sensitive species such as mice and rats secretes mainly corticosterone, of which the glucocorticoid activity is much weaker than that of cortisol. High doses of glucocorticoids severely suppress the immune response and are lethal for corticosteroid-sensitive animals such as rats and mice.

At subnanomolar or nanomolar concentrations, PAF causes platelet aggregation and cortisol release in guinea pigs and dogs, but not in rats and mice. In guinea pigs and dogs, PAF might play a more important role as a potent mediator of immediate hypersensitivity or inflammation than in rats and mice. Glucocorticoids suppress the production and action of chemical mediators, including PAF, and induce phospholipase $\mathrm{A}_{2}$-inhibiting protein (lipocortin I/ annexin I) that affects the arachidonic cascade and release of the PAF precursor, lyso-PAF (Flower \& Rothwell 1994). Glucocorticoids decrease the activity of PAF acetyltransferase in the rat liver and spleen and increase the plasma PAF acetylhydrolase activity (Ihara et al. 1993). Cortisol secretion by PAF that increases under immediate hypersensitivity or more-severe inflammation might represent a life-saving host defense reaction via a negative-feedback mechanism. 


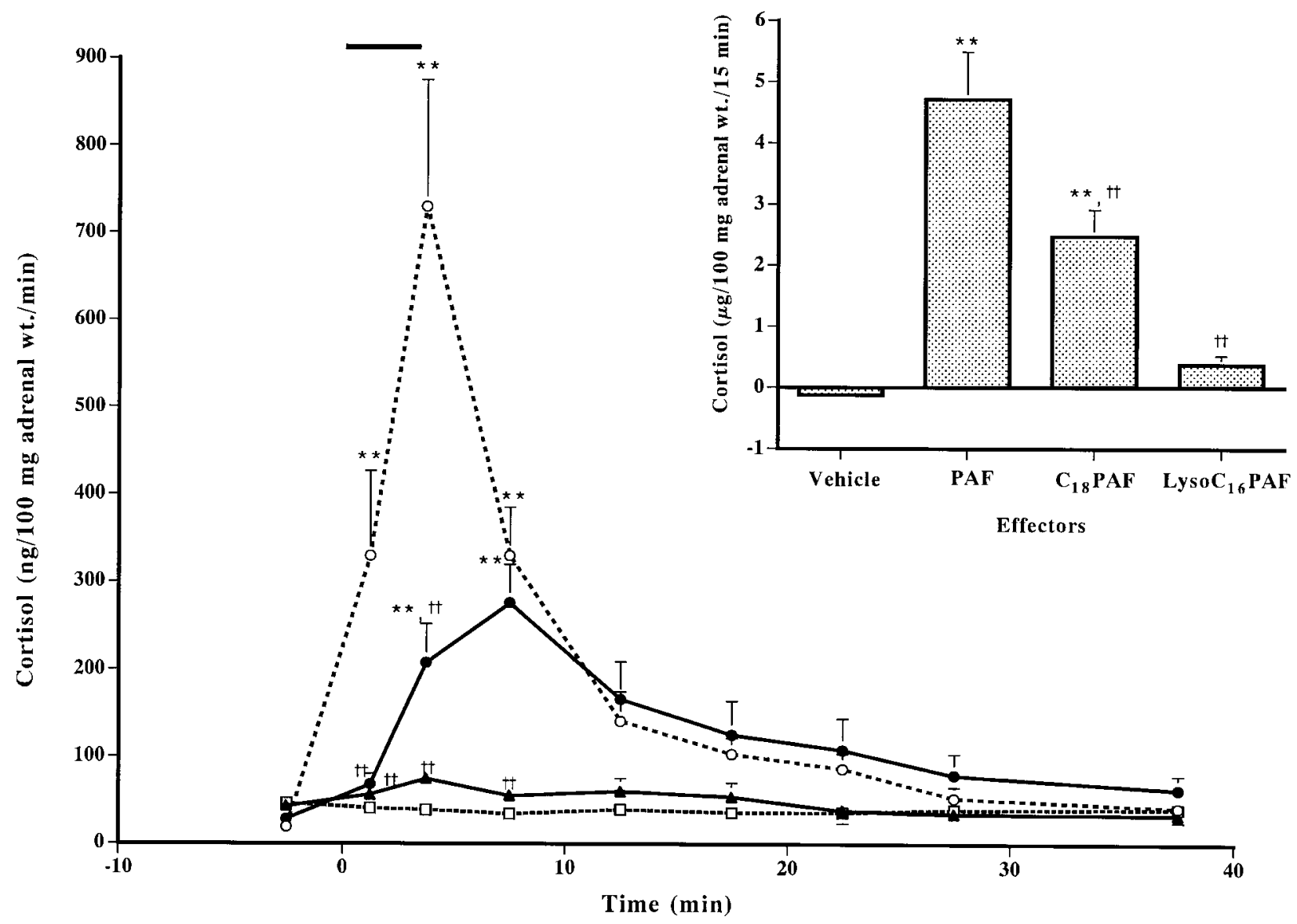

Figure 4 Effects of infusion of $\mathrm{C}_{18}$ PAF and lyso-PAF. Vehicle ( $\square$ ), $10 \mathrm{nM} \mathrm{C}{ }_{18}$ PAF $(\bullet)$ or $10 \mathrm{nM} \mathrm{C} \mathrm{C}_{16}$ lyso-PAF $(\boldsymbol{\Delta})$ was infused over $5 \mathrm{~min}$ and cortisol secretion was compared with that in response to $10 \mathrm{nM}$ PAF $(\bigcirc)$. Inset: total amounts of cortisol secretion in response to vehicle, $\mathrm{PAF}, \mathrm{C}_{18} \mathrm{PAF}$ and $\mathrm{C}_{16}$ lyso-PAF. Values are means \pm s.E.M., $n=6$. $\dagger+P<0 \cdot 01$ versus $\mathrm{PAF}$; ${ }^{* *} P<0 \cdot 01$ versus vehicle control.

CV-3988 and CV-6209 (Terashita et al. 1983, 1987) are structural analogs that competitively antagonize PAF at its receptor. The adrenals had to be perfused with CV3988 before PAF to inhibit PAF-induced cortisol release (Fig. 3). On the other hand, the simultaneous admin- istration of CV-6209 was an effective inhibitor, because CV-6209 is more lipid-soluble and it binds with higher affinity than CV-3988.

Figure 4 shows that an infusion of lyso-PAF did not induce cortisol secretion and that octadecyl-PAF

Table 1 Inhibitory effects of $\mathrm{H}-7$ and $\mathrm{H}-8$ on the PAF-induced secretion of cortisol. The secretory responses to $10 \mathrm{nM}$ PAF with prior treatment with $0 \cdot 25,0 \cdot 5,5$ and $12 \cdot 5 \mu \mathrm{M} \mathrm{H}-7$ or with $0.5,5,12.5$ and $25 \mu \mathrm{M} \mathrm{H}-8$ were compared to responses without prior treatment with the inhibitor. Numbers in parantheses represent percentage changes compared to the corresponding control (vehicle) value (100\%). Values are means \pm S.E.M., $n=6$

\begin{tabular}{|c|c|c|c|c|}
\hline \multirow[b]{2}{*}{ Treatment $(\mu \mathrm{M})$} & \multicolumn{2}{|c|}{$\mathbf{H}-\mathbf{7}(\mu \mathrm{g} / 100 \mathrm{mg}$ adrenal wt./15 min) } & \multicolumn{2}{|c|}{$\mathbf{H - 8}$ ( $\mu \mathrm{g} / 100 \mathrm{mg}$ adrenal wt./15 min) } \\
\hline & & & & \\
\hline Vehicle & $4 \cdot 26 \pm 0 \cdot 54$ & $(100 \cdot 0)$ & $4 \cdot 26 \pm 0 \cdot 54$ & $(100 \cdot 0)$ \\
\hline $0 \cdot 25$ & $4 \cdot 00 \pm 0 \cdot 32$ & $(93.9)$ & - & - \\
\hline $0 \cdot 5$ & $2 \cdot 78 \pm 0 \cdot 80$ & $(65 \cdot 3)$ & $4 \cdot 53 \pm 0.77$ & $(106 \cdot 3)$ \\
\hline 5 & $1 \cdot 64 \pm 0 \cdot 41^{* *}$ & $(38 \cdot 5)$ & $3 \cdot 67 \pm 0 \cdot 46$ & $(86 \cdot 2)$ \\
\hline $12 \cdot 5$ & $1 \cdot 65 \pm 0.27^{* *}$ & $(38 \cdot 9)$ & $2 \cdot 71 \pm 0 \cdot 29$ & $(63 \cdot 6)$ \\
\hline 25 & - & - & $2 \cdot 73 \pm 0 \cdot 55$ & $(64 \cdot 1)$ \\
\hline
\end{tabular}

${ }^{* *} P<0 \cdot 01$ versus vehicle control. 


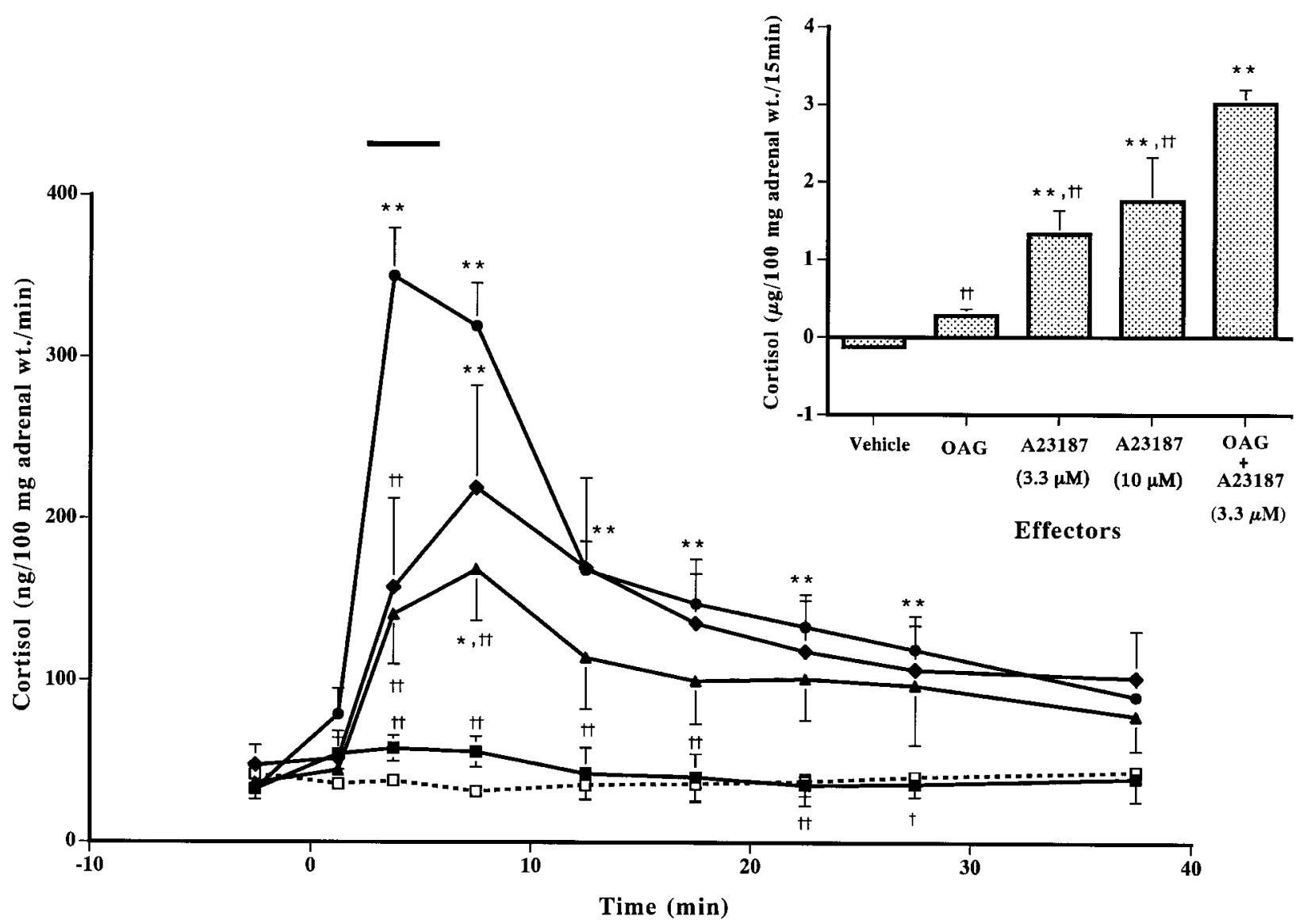

Figure 5 Synergistic effects of OAG and A23187 on cortisol secretion. Vehicle ( $\square$ ), $50 \mu \mathrm{M}$ OAG ( $\mathbf{\square})$, A23187 at $3 \cdot 3$ ( $\mathbf{\Delta}$ ) or $10 \mu \mathrm{M}(\bullet)$, or a mixture of $50 \mu \mathrm{M}$ OAG and $3 \cdot 3 \mu \mathrm{M} \mathrm{A23187}(\mathbf{(})$ was infused (bar above curves) over 5 min and cortisol production was monitored. Inset: total amounts of cortisol secretion in response to vehicle control, $50 \mu \mathrm{M}$ OAG, 3.3 or $10 \mu \mathrm{M} \mathrm{A23187,} \mathrm{and} \mathrm{50 \mu M} \mathrm{OAG} \mathrm{plus}$ $3 \cdot 3 \mu \mathrm{M}$ A23187. Values are means \pm S.E.M., $n=6$. $\dagger P<0 \cdot 05, \dagger+P<0 \cdot 01$ versus OAG plus $A 23187 ;{ }^{*} P<0 \cdot 05,{ }^{*} P<0 \cdot 01$ versus vehicle control.

stimulated less cortisol release than hexadecyl-PAF. Thus, not only the acetyl moiety at the second position in the triglyceride but also the length of the alkyl side chain at the first position is responsible for binding to the specific PAF receptor on adrenocortical cells.

The interactions between ACTH- and PAFregulated steroidogenesis are of considerable interest. N-Methylcarbamyl-PAF, which cannot be metabolized, induces corticosterone release and a PAF antagonist significantly depresses corticosterone release in response to ACTH, forskolin or dibutyryl cAMP in perfused mouse adrenals (Han et al. 1998). PAF and its receptors affect the ACTH-signaling pathway of adrenocortical cells in mice. Our preliminary examinations showed that the cortisol response to PAF after treatment with ACTH seemed much smaller than that after an initial infusion of PAF. By contrast, the cortisol response to ACTH after treatment with PAF seemed to be greater than that after the first infusion. The cortisol response to a mixture of $10 \mathrm{pg} / \mathrm{ml} \mathrm{ACTH}$ and $1 \mathrm{nM}$ PAF was much lower than the arithmetic sum of the amounts of each agent secreted separately $\quad(10 \mathrm{pg} / \mathrm{ml} \quad$ ACTH, $3 \cdot 0 \pm 0 \cdot 6 \mu \mathrm{g} / 100 \mathrm{mg}$ adrenals per $30 \mathrm{~min} ; 1 \mathrm{nM}$ PAF, $2 \cdot 1 \pm 0 \cdot 4 \mu \mathrm{g} / 100 \mathrm{mg}$ adrenals per $30 \mathrm{~min} ; 10 \mathrm{pg} / \mathrm{ml}$ ACTH plus $1 \mathrm{nM}$ PAF, $4 \cdot 0 \pm 0 \cdot 4 \mu \mathrm{g} / 100 \mathrm{mg}$ adrenals per $30 \mathrm{~min} ; n=6)$. Furthermore, the adrenal response of cortisol secretion by repeated exposure to the mixture was fairly reproducible ( $\mathrm{T}$ Shimada, $\mathrm{T}$ Hirose, I Matsumoto \& $\mathrm{T}$ Aikawa, unpublished observations). Consequently, we are examining the intracellular mechanisms of crosstalk between PAF- and ACTH-modulated cortisol secretions in guinea pigs.

The selective inhibitors of protein kinases functioned quite differently. $\mathrm{H}-7$ at 5 and $12 \cdot 5 \mu \mathrm{M}$ abolished PAFinduced cortisol secretion, whereas inhibition by $\mathrm{H}-8$ was not statistically significant (Table 1). Therefore, the PAF-induced secretion of cortisol seems to involve PKCactivated processes.

Angiotensin II, the action of which involves the phosphoinositide-turnover-mediated activation of PKC, 


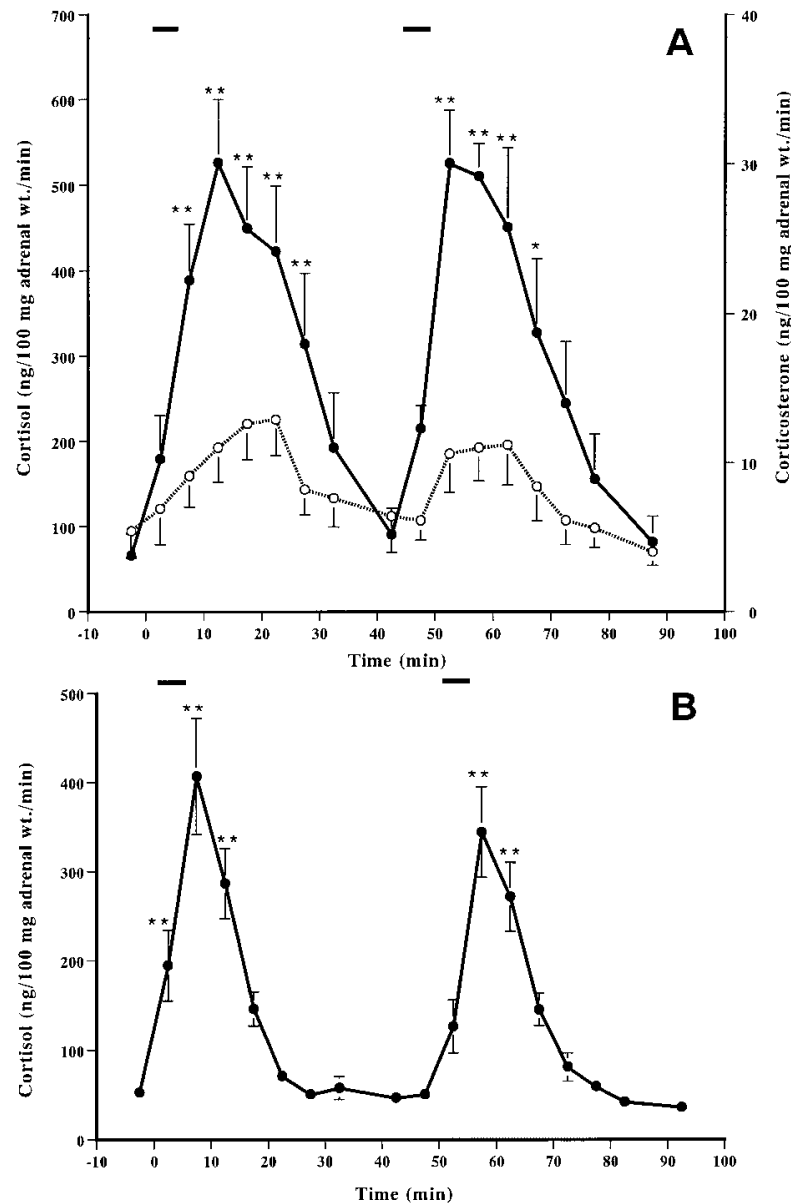

Figure 6 Reproducibility of cortisol response to repeated infusion of ACTH and forskolin. (A) $100 \mathrm{pg} / \mathrm{ml} \mathrm{ACTH}$ or (B) $10 \mu \mathrm{M}$ forskolin was infused twice (bars above curves) over 5 min and cortisol $(\bullet)$ and corticosterone $(\bigcirc)$ production was monitored. Total calculated amounts of cortisol secretion during 30 min after the first and second administrations were $9 \cdot 4 \pm 1 \cdot 5$ and $9 \cdot 4 \pm 1 \cdot 4 \mu \mathrm{g} / 100 \mathrm{mg}$ adrenal weight for ACTH and $4 \cdot 0 \pm 0 \cdot 6$ and $3 \cdot 6 \pm 0 \cdot 6 \mu \mathrm{g} / 100 \mathrm{mg}$ adrenal weight for forskolin. Values are means \pm S.E.M., $n=6$. ${ }^{*} P<0 \cdot 05,{ }^{*} P<0 \cdot 01$ versus basal value (immediately before infusion of stimuli).

stimulates glucocorticoid secretion in bovine (Hadjian et al. 1984, Williams et al. 1989, Viard et al. 1990), human (Lebrethon et al. 1994) and guinea-pig (Nishikawa et al. 1990) adrenocortical fasciculata cells. In contrast, angiotensin II-induced steroidogenesis is somewhat controversial. In rat (Arola et al. 1994), sheep (Viard et al. 1990) and human (Ishizuka et al. 1988) fasciculata cells that contain active PKC, neither angiotensin II nor PKC activators induce steroidogenesis. The PKC activator OAG $(50 \mu \mathrm{M})$ together with A23187 $(3 \cdot 3 \mu \mathrm{M})$ caused cortisol secretion when simultaneously infused in the present study (Fig. 5). The A23187 (3.3 and $10 \mu \mathrm{M})$-induced release of cortisol might have been mediated by an increase in the cytosolic
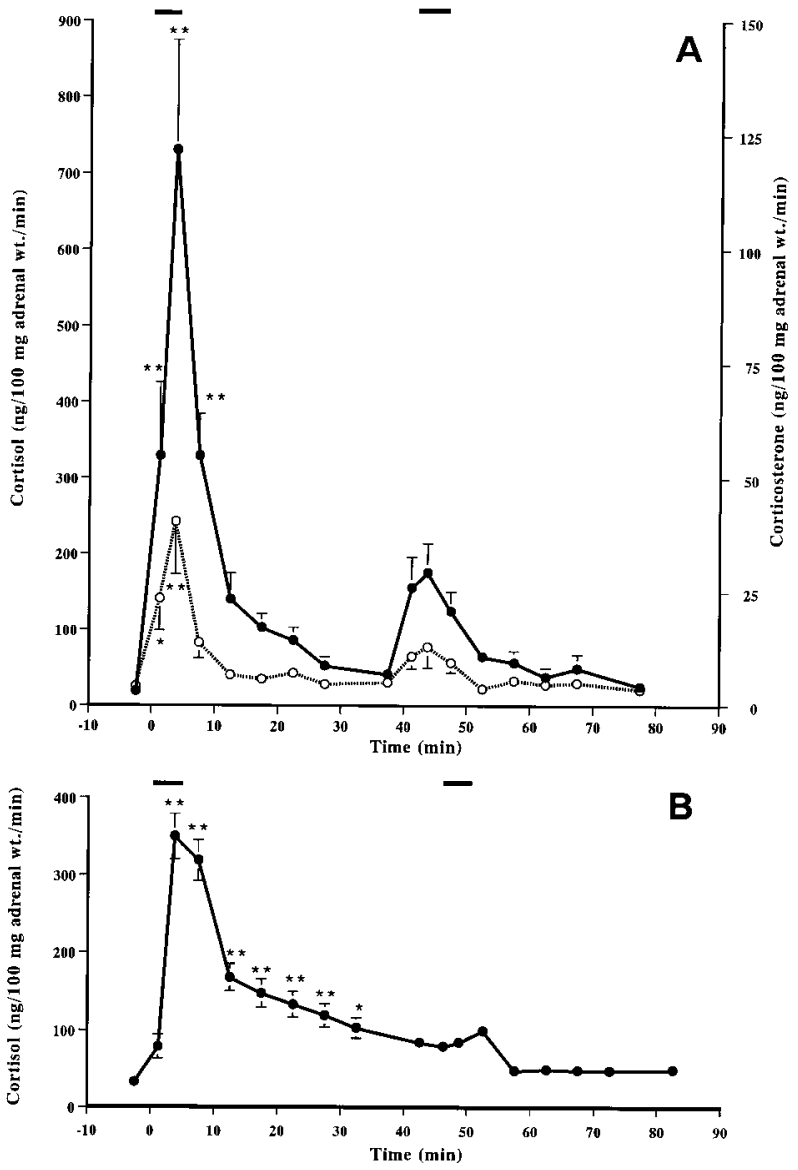

Figure 7 Desensitization of cortisol response to repeated infusions of PAF and OAG plus A23187. (A) $10 \mathrm{nM}$ PAF or (B) $50 \mu \mathrm{M}$ OAG plus $3.3 \mu \mathrm{M} \mathrm{A23187}$ was infused twice (bars above curves) over $5 \mathrm{~min}$ and cortisol $(\bullet)$ and corticosterone $(\bigcirc)$ secretion was monitored. Total calculated amounts of cortisol secretion during 15 min after the first and second responses were $4 \cdot 7 \pm 0 \cdot 8$ and $1 \cdot 5 \pm 0 \cdot 3 \mu \mathrm{g} / 100 \mathrm{mg}$ adrenal weight for PAF and $3 \cdot 0 \pm 0 \cdot 2$ and $0 \cdot 7 \pm 0 \cdot 1 \mu \mathrm{g} / 100 \mathrm{mg}$ adrenal weight for OAG plus A23187 respectively $(P<0 \cdot 01$ for second response versus first response in each case, by paired $t$-test). Values are means \pm S.E.M., $n=6$. ${ }^{*} P<0 \cdot 05,{ }^{*} P<0 \cdot 01$ versus basal value (immediately before infusion of stimuli).

concentration of $\mathrm{Ca}^{2+}$ ions, with consequent modulation of reactions that are dependent on PKC and/or calmodulin.

Figure 6 shows that the cortisol response to the repeated administration of ACTH or forskolin, an adenylcyclase activator, was reproducible. These results suggest that protein kinase A-induced steroidogenesis is neither up- nor down-regulated. By contrast, cortisol secretion in response to repeated infusions of PAF or OAG plus A23187 became desensitized, as the second response was much smaller than the first. A G-protein-coupled receptor kinase or activated PKC might exert a negative-feedback effect that results in the direct inactivation of PKC itself or the inhibition of phospholipase $\mathrm{C}$ through inactivation of 
the receptor by phosphorylation (Izumi \& Shimizu 1995, Kishimoto et al. 1989). These results support the notion that PAF activates cortisol release via calcium- and phospholipid-dependent PKC activation.

The present study confirmed that PAF at subnanomolar concentrations evokes cortisol output via a mechanism involving PKC in the guinea-pig adrenal gland.

\section{Acknowledgements}

We thank Mr Yukinori Hirayama for skillful technical assistance. This study was supported in part by grants from the Ministry of Education, Science and Culture, Japan. The use of the Laboratory Animal Center for Biomedical Research at the Medical School of Nagasaki University is gratefully acknowledged. The authors declare that there is no conflict of interest that would prejudice the impartiality of this scientific work.

\section{References}

Aikawa T, Hirose T, Matsumoto I, Morikawa T, Shimada T, Mine Y, Tsujimoto Y \& Tsuji Y 1991 Effect of platelet-activating factor on cortisol and corticosterone secretion by perfused dog adrenal. Lipids 26 1108-1111.

Ammit AJ \& O'Neill C 1997 Studies of the nature of the binding by albumin of platelet-activating factor release from cells. Journal of Biological Chemistry 272 18772-18778.

Arola J, Heikkila P, Voutilainen R \& Kahri AI 1994 Protein kinase C signal transduction pathway in ACTH-induced growth effect of rat adrenocortical cells in primary culture. Journal of Endocrinology 141 285-293.

Baldi E, Bonaccorsi L, Finetti G, Luconi M, Muratori M, Susini T, Forti G, Serio M \& Maggi M 1994 Platelet-activating factor in human endometrium. Journal of Steroid Biochemistry and Molecular Biology 49 359-363.

Braquet P, Touqui L, Shen TY \& Vargaftig BB 1987 Perspectives in platelet-activating factor research. Pharmacological Reviews 39 97-145.

Buxton DB, Shukla SD, Hanahan DJ \& Olson MS 1984 Stimulation of hepatic glycogenolysis by acetylglyceryl ether phosphorylcholine. Journal of Biological Chemistry 259 1468-1471.

Caramelo C, Fernandez-Gallardo S, Marin-Cao D, Inarrea P, Santos JC, Lopez-Novoa JM \& Sanchez-Crespo M 1984 Presence of platelet-activating factor in blood from humans and experimental animals. Its absence in anephric individuals. Biochemical and Biophysical Research Communications 120 789-796.

Coëffier E, Borrel M-C, Lefort J, Chignard M, Broquet C, Heymans F, Goldfroid J-J \& Vargaftig BB 1986 Effects of PAF-acether and structural analogues on platelet activation and bronchoconstriction in guinea-pigs. European Journal of Pharmacology 131 179-188.

Flower RJ \& Rothwell NJ 1994 Lipocortin-1: cellular mechanisms and clinical relevance. Trends in Pharmacological Sciences 15 71-76.

Hadjian AJ, Culty M \& Chambaz M 1984 Stimulation of phosphatidylinositol turnover by acetylcholine, angiotensin II and ACTH in bovine adrenal fasciculata cells. Biochemica et Biophysica Acta 804 427-433.

Han L, Yang H, Shimada T, Hirose T, Koyanagi M, Matsumoto I, Iwasaki K \& Aikawa T 1998 Effect of PAF receptor antagonists on adrenocortical secretion induced by ACTH in normal and athymic nude mice. Life Sciences 62 715-726.
Hirose T 1977 Cortisol and corticosterone productions of isolated adrenal cells in neonatal rabbit. Acta Endocrinologica 84 349-356.

Ihara Y, Frenkel RA \& Johnston JM 1993 Hormonal regulation of platelet-activating factor-acetyltransferase activity in rat tissues. Archives of Biochemistry and Biophysics 301 275-281.

Ishizuka T, Miura K, Nagao S \& Nozawa Y 1988 Differential redistribution of protein kinase $\mathrm{C}$ in human aldosteronoma cells and adjacent adrenal cells stimulated with ACTH and angiotensin II. Biochemical and Biophysical Research Communications 155 643-649.

Izumi T \& Shimizu T 1995 Platelet-activating factor receptor: gene expression and signal transduction. Biochimica et Biophysica Acta 1259 317-333.

Kishimoto A, Mikawa K, Hashimoto K, Yasuda I, Tanaka S, Tominaga M, Kuroda T \& Nishizuka Y 1989 Limited proteolysis of protein kinase $\mathrm{C}$ subspecies by calcium-dependent neutral protease (calpain). Journal of Biological Chemistry 264 4088-4092.

Lebrethon MC, Jaillard C, Defayes G, Begeot M \& Saez JM 1994 Human cultured adrenal fasciculata-reticularis cells are targets for angiotensin-II: Effects on cytochrome P450 cholesterol side-chain cleavage, cytochrome P450 17 $\alpha$-hydroxylase, and $3 \beta$-hydroxysteroid-dehydrogenase messenger ribonucleic acid and proteins and on steroidogenic responsiveness to corticotropin and angiotensin-II. Journal of Clinical Endocrinology \& Metabolism 78 $1212-1219$.

Matsumoto I, Oomura Y, Nishino H, Nemoto S, Aou S \& Aikawa T 1994 Effects of 2-buten-4-olide, an endogenous satiety substance, on plasma glucose, corticosterone, and catecholamines. American Journal of Physiology - Regulatory Comparative and Integrative Physiology 266 R 413-R418.

Mokuda O, Sakamoto Y, Kawagoe R, Ubukata E \& Shimizu N 1992 Epinephrine augment cortisol secretion from isolated perfused adrenal glands of guinea pigs. American Journal of Physiology Endocrinology and Metabolism 262 E806-E809.

Nishikawa T, Yoshida A, Tamura Y \& Yoshida S 1990 Involvement of protein kinase $\mathrm{C}$ in the regulation of cortisol production by guinea pig adrenocortical cells. Hormone and Metabolic Research 22 29-32.

Pelosin JM, Keramidas M \& Chambaz EM 1991 Production of platelet-activating factor is a component of the angiotensin II-protein kinase C activation pathway in bovine adrenocortical cells. Biochemical Journal 278 29-34.

Rougeot C, Junier M-P, Minary P, Weidenfeld J, Braquet P \& Dray F 1990 Intracerebroventricular injection of platelet-activating factor induces secretion of adrenocorticotropin, beta-endorphin and corticosterone in conscious rats: A possible link between the immune and nervous systems. Neuroendocrinology $\mathbf{5 1}$ 267-275.

Shimizu T, Honda Z, Nakamura M, Bito H \& Izumi T 1992 Platelet-activating factor receptor and signal transduction. Biochemical Pharmacology 44 1001-1008.

Söling H-D, Eibl H \& Fest W 1984 Acetylcholine-like effects of 1-O-alkyl-2-acetyl-sn-glycero-3-phosphocholine ('platelet-activating factor') and its analogues in exocrine glands. European Journal of Biochemistry 144 65-72.

Stafforini DM, Prescott SM \& McIntyre TM 1987 Human plasma platelet-activating factor acetylhydrolase. Purification and properties. Journal of Biological Chemistry 262 4223-4230.

Terashita Z, Tsushima S, Yoshioka Y, Nomura H, Inada Y \& Nishikawa K 1983 CV-3988, a specific antagonist of platelet activating factor (PAF). Life Sciences 32 1975-1982.

Terashita Z, Imura Y, Takatani M, Tsushima S \& Nishikawa K 1987 CV6209, a high potent antagonist of platelet activating factor in vivo and in vitro. Journal of Pharmacology and Experimental Therapeutics 242 263-268.

Viard I, Rainey WE, Capponi AM, Begeot M \& Saez JM 1990 Ovine adrenal fasciculata cells contain angiotensin-II receptors 
coupled to intracellular effectors but are resistant to the steroidogenic effects of this hormone. Endocrinology 127 2071-2078.

Williams BC, Lightly ERT, Ross AR, Bird IM \& Walker SW 1989 Characterization of the steroidogenic responsiveness and ultrastructure of purified zona fasciculata/reticularis cells from bovine adrenal cortex before and after primary culture. Journal of Endocrinology 121 317-324.

Yang H, Koyanagi M, Matsumoto I, Shimada T, Han L \& Aikawa T 1995 Corticosterone secretion in response to serotonin and ACTH by perfused adrenal of normal and athymic nude mice. Life Sciences 56 1727-1739.

Received in final form 28 October 2004

Accepted 3 November 2004

Made available online as an

Accepted Preprint 16 November 2004 